\title{
Burmeistera minutiflora (Campanulaceae-Lobelioideae), a new species from the high Andes of Antioquia (Colombia) with the smallest flowers in the genus
}

\author{
Javier Garzón Venegas, Favio González" \& Jorge Mario Vélez Puerta \\ Instituto de Ciencias Naturales, Universidad Nacional de Colombia, A.A. 7495, Bogotá, Colombia; fagonzalezg@unal.edu.co
}

\begin{abstract}
Garzón Venegas, J., González, F. \& Vélez Puerta, J.M. Burmeistera minutiflora (Campanulaceae-Lobelioideae), a new species from the high Andes of Antioquia (Colombia) with the smallest flowers in the genus. Anales Jard. Bot. Madrid 69(2): 243-246.

Burmeistera minutiflora (Campanulaceae-Lobelioideae), a new species of sect. Barbatae, is here described, illustrated, and keyed out with respect to other species of the genus with small flowers (i.e. corolla tube $<1 \mathrm{~cm}$ long). The new species is a small herb that grows in the understory of remnants of cloud montane forests of the Western cordillera of Antioquia, Colombia. The dimensions of the corolla and the berries correspond without doubts to the smallest size of reproductive structures in the genus. The small floral size contrasts with the colorful, bright red and yellow corollas.
\end{abstract}

Key Words: Flora of Antioquia, Flora of Colombia, cloud forests, paramo, subparamo, Las Orquídeas National Natural Park.

\section{INTRODUCTION}

Burmeistera, described by J.J. Triana (1854), is the fourth largest genus of the Lobelioideae. Karsten \& Triana (1856), Zahlbruckner (1906, 1915), Gleason (1925), Wimmer (1931, 1932, 1943, 1953, 1968), McVaugh (1949, 1965), Nash (1976), Wilbur (1976a, 1976b, 1981), Jeppesen (1981), Stein (1987), Lammers (1998, 2007a, 2007b), and Lammers \& Maas (1998), among others, have contributed to the knowledge of the genus. In the ongoing treatment of the genus for Flora of Colombia the estimated number of Burmeistera species has increased to 112 (Garzón \& al. 2012; Garzón \& González, in prep.). Burmeistera occurs in Honduras, Guatemala, Costa Rica, Panama, Colombia, Venezuela, Ecuador, and Peru (Lammers, 2002). The species of Burmeistera are herbs, subshrubs or shrubs, rarely hemi-epiphytic. Most of the species grow in cloud montane forests between 1000$3000 \mathrm{~m}$ in elevation with extremely narrow distributions.

The most comprehensive revisions of Burmeistera were written by Wimmer $(1931,1932,1943,1953,1968)$, who recognized about 80 species arranged in two sections, Barbatae E. Wimm., and Imberbes (nom. invalid. = sect. Burmeistera Lammers; see Lammers, 1998), based on the indument of the apical margin of the anther tube. Although the monophyly of these two sections has been questioned by Knox \& al. (2008), the presence of a tuft of trichomes in the apex of the ventral anthers in preanthetic flowers remains as a reliable diagnostic field character at a specific level (Garzón \& al., 2012).

The first Colombian species were described by Kunth (1818, under Lobelia), but then Karsten \& Triana (1856),

\section{Resumen}

Garzón Venegas, J., González, F. \& Vélez Puerta, J.M. Burmeistera minutiflora (Campanulaceae-Lobelioideae), una nueva especie de los Andes de Antioquia (Colombia) con las flores más pequeñas del género. Anales Jard. Bot. Madrid 69(2): 243-246 (en inglés).

Se describe Burmeistera minutiflora (Campanulaceae-Lobelioideae), una nueva especie de la sect. Barbatae, y se ilustra e incluye en una clave en la que se contrasta con otras especies de flores diminutas (i.e. con corola $<1$ $\mathrm{cm})$. La nueva especie es una hierba pequeña, que crece en el sotobosque de remanentes de bosques nublados de la Cordillera Occidental de Antioquia, Colombia. Las pequeñas dimensiones de la corola y de las bayas corresponden si lugar a dudas a las estructuras reproductivas de menor tamaño conocidas en el género. El pequeño tamaño de las flores contrasta con la vivacidad de las corolas rojas brillantes y amarillas.

Palabras Clave: Flora de Antioquia, Flora de Colombia, bosques nublados, páramos, subpáramos, Parque Nacional Natural Las Orquídeas.

Zahlbruckner (1906, 1915), Wimmer (1931, 1932, 1943, 1953, 1968), and most recently McVaugh (1965), Luteyn (1986), Lozano and Galeano (1986), Lammers \& Maas (1998) and Lammers (2002) have described most of the species present in Colombia, where the genus reaches its highest diversity. The main species-level diagnostic characters in Burmeistera are the overall pubescence of the plant, the leaf architecture, the presence or absence of bracts at the base or the proximal third of the floral peduncle, the shape and size of the hypanthium, the calyx lobes, the shape, size and color of the corolla, and the size, shape, color, and consistency of the berries.

\section{MATERIAL AND METHODS}

Specimens examined are deposited in the following herbaria: COL, HUA, JAUM, and MEDEL (abbreviations following Holmgren \& al., 1990, Index Herbariorum). Isotypes of the new species will be distributed to HUA, MA, and NY. The photographs that illustrate the new species were taken with a Canon EOS 7D digital camera. Measurements below $5 \mathrm{~mm}$ were taken using a Metric Mini Scale \#1 by Electron Microscopy Sciences (EMS).

\section{RESULTS AND DISCUSSION}

While working on a taxonomic revision of the Colombian Burmeistera, we found several unidentified specimens collected in the department of Antioquia, mostly at the northern slopes of the Western Cordillera (including Las Orquídeas National Natural Park). These specimens with remarkably 

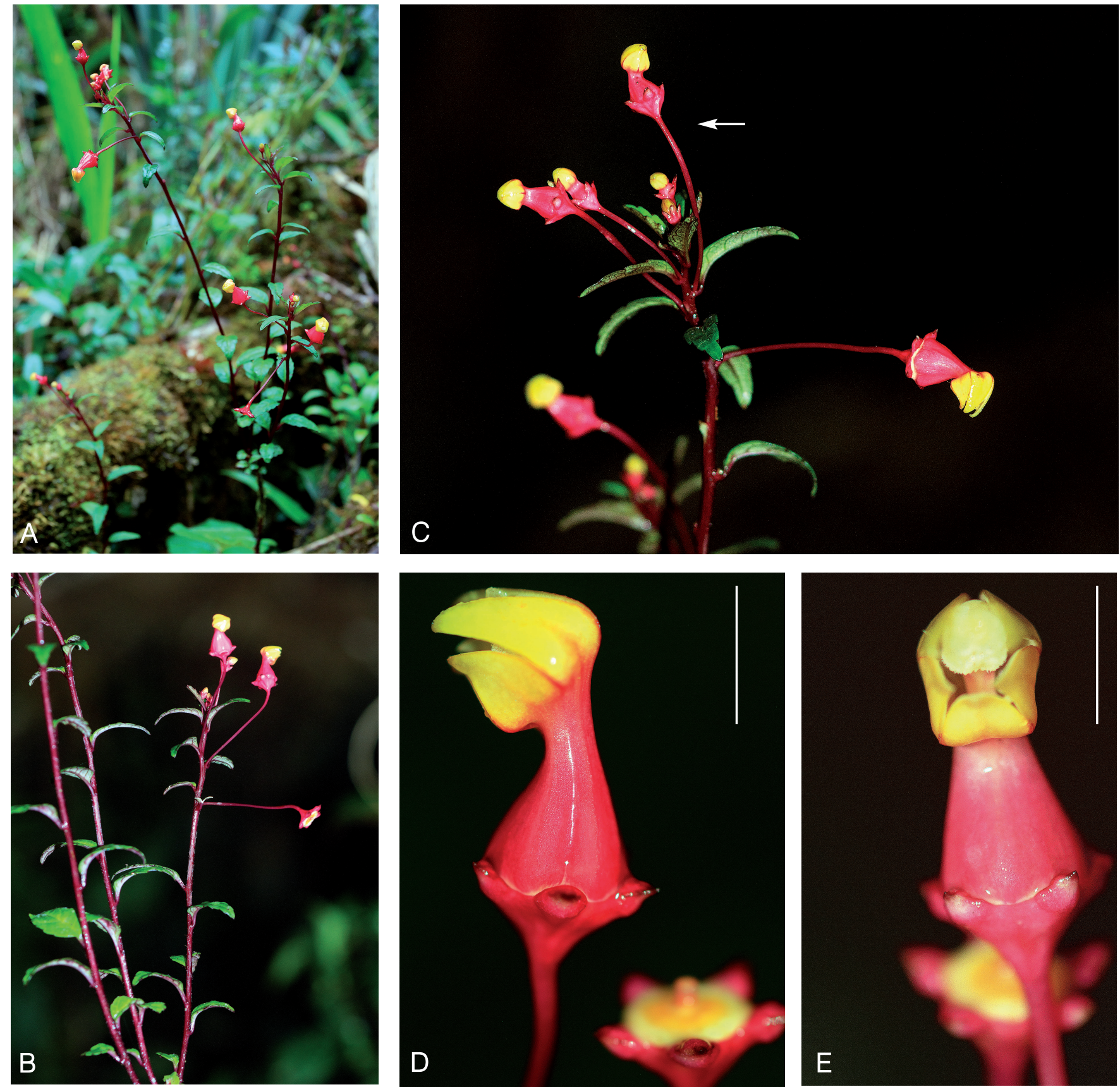

Fig. 1. Burmeistera minutiflora. A, B, plant in its natural habitat; C, detail of a flowering shoot; note resupination from flower four (arrow) onwards; $\mathbf{D}, \mathbf{E}$, flower in lateral (D), and frontal (E) views. Scale bars $=5 \mathrm{~mm}$ (All from the holotype).

small flowers did not match any of the known species to date. Here we describe this new species, which belongs to series Barbatae sensu E. Wimmer (1931, 1932, 1943).

\section{Burmeistera minutiflora Garzón \& F. González, sp. nov.}

Type: Colombia. Antioquia: Abriaquí, Parque Nacional Natural Las Orquídeas, vereda Piedras, entre el extremo norte de la cuchilla de Morro Pelao y La Mina, 6 $37^{\prime} \mathrm{N}-6^{\circ} 40^{\prime} \mathrm{N}$, 76 $6^{\circ}$ 'W-76 ${ }^{\circ} 11^{\prime} \mathrm{W}, 2800-3350$ m, 8 Feb 2012 (fl, fr), $M$. González, J. Betancur, A. Duque, W. Galvis, F. Gómez, O. Laverde, M. Londoño, M. Rios E J. Serna 945 (holotype, COL; isotypes, HUA, MA, NY, to be distributed). (Fig. 1).
Small erect, terrestrial herbs to $30 \mathrm{~cm}$ high, branching from the base, with milky latex. Stems fleshy, terete, slender, glabrous, maroon, internodes $0.5-1.5(2) \mathrm{cm}$ long. Leaves spirally arranged; petiole $3-10 \mathrm{~mm}$ long, maroon, glabrous; distal leaves isomorphic but slightly reduced with respect to the proximal leaves; lamina ovate to narrowly ovate, (1.5)1.8$2.8(3.8) \times(0.6) 1-1.5 \mathrm{~cm}$, slightly fleshy, adaxial surface bright green, abaxial surface pale green or maroon-veined, glabrous on both sides, base slightly asymmetric, convex to rounded, apex acute, margin entire basally, serrulate along the distal $1 / 3$, with 6-10(16) teeth on each side, in one size class, each tooth with a distal callosity, venation semicraspedodromous, 
with 4-6 pairs of secondary veins, irregularly spaced, generally excurrent with the primary vein, higher order veins reticulate. Flowers solitary in the axils of upper leaves, resupinated; peduncles ebracteate, bright red, glabrous, $1.8-3.1 \mathrm{~cm}$ long at anthesis; hypanthium obconic, $2-3 \mathrm{~mm}$ long, 3-5(7) $\mathrm{mm}$ diam., glabrous, calyx lobes five, triangular, patent, $1.5-2 \times$ 1.5-2 mm, margins entire, leaving broad (1.5-2 mm wide) sinuses between lobes; corolla suberect, glabrous, $0.8-1.1 \mathrm{~cm}$ long, tube conical, 5-7 mm long, 4-6 mm basal diameter, 2$3 \mathrm{~mm}$ distal diameter, bright red, lobes five, bright yellow, glabrous, all lobes ovate-triangular, slightly falcate, with apices acute to shortly acuminate, dorsal lobes 4.5-5.5 × 2-2.5 $\mathrm{mm}$, lateral lobes $3-4 \times 1.5-2 \mathrm{~mm}$, ventral lobe $4-5 \times 1.5-2$ $\mathrm{mm}$; androecium shortly exserted (by c $1.5 \mathrm{~mm}$ ) between the dorsal lobes, filament tube erect, 6-7 mm long, glabrous, anther tube 1.8-2 mm diam., obliquely cup-shaped, glabrous, dorsal anthers three, $4-4.5 \mathrm{~mm}$ long, ventral anthers two, 2$3.5 \mathrm{~mm}$ long, sparsely pubescent with an apical tuft of white woolly hairs to $0.5 \mathrm{~mm}$ long. Berry turbinate, $3-5(7) \mathrm{mm} \times 6$ $8 \mathrm{~mm}$ (in siccus), bright red, lobes triangular 1.5-2 $\times 1-5$; seeds rhomboid, to $1 \times 0.3 \mathrm{~mm}$.

Etymology. The specific epithet refers to the size of the flowers, which corresponds to the smallest flower size of any known species in the genus Burmeistera.

Burmeistera minutiflora is easily distinguished by the bicolor (bright red and yellow) and the small corollas $(<1.1 \mathrm{~cm}$ long), the smallest of the genus. Overall, it is similar to $B$. antioquensis Garzón \& J.M. Vélez (Garzón \& al., 2012, in press), but the corolla alone is similar to that of B. kirkbridei Wilbur, from Panama. However, the latter species falls into sect. Imberbes, as the apex of the two ventral anthers does not possess a tuft of apical hairs. The key below summarizes the main differences between the species with corolla tube $<1 \mathrm{~cm}$ from Costa Rica, Panama, Colombia, and Ecuador.

Distribution and ecology. With 23 species of Burmeistera (Idárraga, 2011), plus the recently described new species (Garzón \& al., 2012), Antioquia is most likely the department of Colombia with the highest diversity of the genus. B. minutiflora has been collected in elevations between $2800-3550 \mathrm{~m}$, in some of the few remnants of paramo and subparamo existing in the department. The localities where the new species has been collected fall into the superhumid paramo ecosystems, corresponding to the bp-M category, following Espinal (2011). The species could be under critical threat, because of the narrow distribution in fragile habitats that undergoes continuous fragmentation and destruction.

The species has been collected in flower in September, and in flower and fruit in February, April and November, which indicates that it has a long flowering season. Another interesting issue for discussion is the type of pollination of the new species. There is an overwhelming dominance of species of Burmeistera visited by bats and hummingbirds (Muchhala, 2006) with a considerable amount of variation in traits like the length and color of the corolla tube and lobes, odor, and the stigma exertion, being the width of the corolla aperture the most critical for pollinator specialization. The reduction observed in corolla sizes in B. minutiflora strongly precludes that most of possible visitors in other species could act as effective pollinators. Instead, the display of the yellow lobes and stigma as well as the narrow corolla aperture suggests an evolution towards an entomophilous pollination syndrome, yet undescribed for this genus.

\section{Additional specimens examined}

COLOMBIA. Antioquia: Urrao, inspección Jaiperá, vereda El Chuscal, páramo de Frontino, sitio Llanogrande, 3000-3390 m, 6²7’ N, 76²4.6’W, 4IV-1989 (fl, fr), R. Callejas \& al. 7498 (HUA). Near Summit of Morro Pelado, 3300 m, along Anocosca-Abriaquí camino, 15 Mar 1944 (fl), E. L. Core 464 (US). Abriaquí, Parque Nacional Natural Las Orquídeas, sector Cuchilla de Morro Pelao (accediendo por La Mina, Río Piedras arriba), 6037'15.22”N, 769'28.8”W, 3400-3450 m, 5-II-2012 (fl, fr), M. González E al. 879 (COL, NY). Urrao, páramo de Frontino, El Río, 3115 m, 10/19-XI1984 (fl, fr), R. Londoño E al. 365 (COL, MEDEL). Urrao, páramo de Frontino, vertiente oriental, cuchilla de Frontino, 6 $6^{\circ} 30^{\prime} \mathrm{N}, 76^{\circ} 7^{\prime} \mathrm{W}, 3550 \mathrm{~m}, 10$ IX-2000 (fl), J.A. Pérez \& N. Parra 1514 (MEDEL). Abriaquí, vereda San José, Parque Nacional Natural "Las Orquídeas", camino de San José a La Quiebra, 6³5' N, 76¹0'W, 2980 m, 30-IV-1990 (fl, fr), J.G. Ramirez \& al. 3874 (JAUM, MEDEL).

\section{KEY FOR THE SPECIES OF BURMEISTERA WITH COROLLA TUBE < 1 CM LONG.}

1. Apex of the ventral anthers glabrous or all the anthers with evenly distributed short trichomes (Sect. Imberbes) .......................... 2

1. Apex of the ventral anthers with a long tuft of barbate trichomes (Sect. Barbatae)

2. Lamina of the leaf elliptic, oblong or ovate. Lobes of corolla triangu-

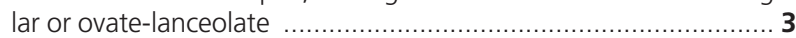

2. Lamina of the leaf lanceolate. Lobes of corolla filiform. Colombia and Ecuador ............................................ B. rostrata Jeppesen

3. Flowers sparsely arranged in the axils of upper leaves. Corollas with bright colors

3. Flowers tightly arranged along the axils of very reduced (bracteiform) leaves, appearing corymbiform. Corolla dull. Colombia and Ecuador B. multiflora Zahlbr.

4. Lamina of the leaf elliptic, to $7 \mathrm{~cm}$ long, with 5 or 6 secondary veins Panama

B. kirkbridei Wilbur

4. Lamina of the leaf ovate to oblong, $7.5-12 \mathrm{~cm}$ long, with ca. $12 \mathrm{sec}$ ondary veins. Ecuador ......... B. rubrosepala (E. Wimm.) E. Wimm.

5. Corollas with bright colors, fuchsia, pink, or bright red ............ 10

5. Corollas with dull colors, green or pale yellow .......................6 6

6. Flowers solitary in the axis of upper leaves. Corolla glabrous or puberulent....

6 . Flowers in terminal corymbiform inflorescences. Corolla villous. Colombia, Ecuador

B. lutosa E. Wimm.

7. Plants glabrous. Sepals $1-3 \mathrm{~mm}$ long .................................. 8

7. Plants puberulent. Sepals 3.5-5 mm long. Panama.... B. dukei Wilbur

8. Leaves with a submarginal vein. Hypanthium as long as wide, to 5 $\mathrm{mm}$ long

8. Leaves lacking a submarginal vein. Hypanthium longer than wide, to $8 \mathrm{~mm}$ long. Colombia .................... B. xerampelina E. Wimm.

9. Lamina of the leaf $5-9 \mathrm{~cm}$ long, with 9 to 11 secondary veins. Costa Rica ....................................... B. coleoides (Vatke) E. Wimm.

9. Lamina of the leaf $9-12 \mathrm{~cm}$ long, with 8 or 9 secondary veins. Costa Rica, Panama ....................................... B. parviflora E. Wimm.

10. Plants glabrous. Lobes of the corolla forming an obtuse angle with respect to the tube

10. Plants puberulous. Lobes of the corolla forming an angle of $90^{\circ}$ with respect to the tube. Colombia .......................Burmeistera sp. 1

(=B. luteynii Garzón \& J.M. Vélez, in press)

11. Leaves distichous. Lamina of the leaf oblong to elliptic, with $6-8 \mathrm{sec}$ ondary veins. Lobes of the calyx 3-7 mm long, leaving a narrow sinus (1/3 of the width of the calyx lobe) between them. Corolla $1.5-2 \mathrm{~cm}$ long, homogeneously bright red, dorsal lobes 9-13 mm long, lateral lobes 7.3-11 mm long. Filament tube woolly. Colombia

.Burmeistera sp. 2

(=B. antioquensis Garzón \& J.M. Vélez, in press) 
11. Leaves spirally arranged. Lamina of the leaf ovate to narrowly ovate, with 4-6 secondary veins. Calyx lobes $1.5-2 \mathrm{~mm}$ long, leaving a sinus as broad as the calyx lobe between them. Corolla $0.8-1.1 \mathrm{~cm}$ long, bicolor, bright red, the limb yellow, dorsal lobes 4.5-5.5 mm long, lateral lobes 3-4 mm long. Filament tube glabrous

B. minutiflora

\section{ACKNOWLEDGEMENTS}

We thank the Fundación para la Promoción de la Investigación y la Tecnología, Banco de la República, and the Facultad de Ciencias and the Dirección Nacional de Investigaciones, Universidad Nacional de Colombia, for financial support of this research (Projects 2413/2009 and 201010011272 to FG). Thanks also to the curators of the herbaria HUA, JAUM, MEDEL, and NY. We also acknowledge M.F. González for the excellent photographs that illustrate the new species, and J. Betancur (National University of Colombia) and P. Pedraza (The New York Botanical Garden) for making excellent collections of lobelioids under the project "Flora de plantas vasculares del Parque Nacional Natural Las Orquídeas", funded by the National Science Foundation (NSF grant DEB 1020623). Finally, we thank an anonymous reviewer for thoughtful comments on the manuscript.

\section{REFERENCES}

Espinal, L.S. 2011. Zonas de vida del departamento de Antioquia. In: R. Callejas-Posada \& A. Idárraga (eds.), Flora de Antioquia. Catálogo de las Plantas Vasculares. Introducción 1: 235-289. Universidad de Antioquia, Missouri Botanical Garden \& Oficina de Planeación departamental de la Gobernación de Antioquia, Editorial D’Vinni, Bogotá.

Garzón, J., J.M. Vélez Puerta \& F. González. 2012. Three new species of Burmeistera (Campanulaceae-Lobelioideae) from Colombia. Brittonia (in press).

Gleason, H.A. 1925. Studies on the flora of northern South America-IV: The genus Burmeistera. Bulletin of the Torrey Botanical Club 52: 93-104.

Idárraga, A. 2011. Campanulaceae. In: A. Idárraga, R. Ortiz, R. Callejas \& M. Merello (eds.), Flora de Antioquia. Catálogo de las Plantas Vasculares, Listado de las plantas vasculares del departamento de Antioquia 2: 384 390. Universidad de Antioquia, Missouri Botanical Garden \& Oficina de Planeación departamental de la Gobernación de Antioquia, Editorial D’Vinni, Bogotá.

Jeppesen, S. 1981. Lobeliaceae. In: G. Harling \& B. Sparre (eds.), Flora of Ecuador 14: 9-170. Swedish Natural Science Research Council. Stockholm.

Karsten, H. \& J.J. Triana. 1856. Plantae Columbianae. Burmeistera Karst. et Triana. Lobeliacearum gen. nov. Linnaea 28: 444-446.

Knox, E.B., A.M. Muasya \& N. Muchhala. 2008. The predominantly South American clade of Lobeliaceae. Systematic Botany 33: 462-468.

Kunth, K.S. 1818. Campanulaceae Juss. Nova Genera et Species Plantarum 3: 300-322, t. 265-272. Librairie Grecque-Latine-Allemande, Paris.

Lammers, T.G. 1998. Review of the neotropical endemics Burmeistera, Centropogon, and Siphocampylus (Campanulaceae: Lobelioideae), with description of 18 new species and a new section. Brittonia 50: 233-262.

Lammers, T.G. 2002. Seventeen new species of Lobelioideae (Campanulaceae) from South America. Novon 12: 206-233.
Lammers, T.G. 2007a. Campanulaceae. In: K. Kubitzki (ed.), The Families and Genera of Vascular Plants 8: 26-56. Springer-Verlag, Berlin, New York.

Lammers, T.G. 2007b. World checklist and bibliography of Campanulaceae. Royal Botanic Gardens, Kew, U.K.

Lammers, T.G. \& P.J.M. Maas. 1998. First report of the genus Burmeistera (Campanulaceae) from Honduras. Sida 18:363-364.

Lozano, G. \& G. Galeano. 1986. Una nueva especie de Burmeistera (Campanulaceae) de Colombia. Caldasia 15(71-75):53-56.

Luteyn, J.L. 1986. A new Burmeistera (Campanulaceae: Lobelioideae) from western Colombia. Systematic Botany 11: 474-476.

McVaugh, R. 1949. Seven new species of Lobelioideae (Campanulaceae). Journal of the Washington Academy of Sciences 39: 157-162.

McVaugh, R. 1965. South American Lobelioideae new to science. Annals of the Missouri Botanical Garden 52:399-409.

Muchhala, N. 2006. The pollination biology of Burmeistera (Campanulaceae): specialization and syndromes. American Journal of Botany 93 1081-1089

Nash, D.L. 1976. Campanulaceae. In: D.L. Nash, J.V.A. Dieterle (eds.), Flora of Guatemala. Fieldiana, Botany 24: 396-431.

Stein, B.A. 1987. Synopsis of the genus Burmeistera (Campanulaceae: Lobelioideae) in Peru. Annals of the Missouri Botanical Garden 74: 494-496.

Triana, J.J. 1854. Nuevos jeneros i especies de plantas para la flora neo-granadina. Imprenta del Neo-Granadino. Bogotá.

Wilbur, R.L. 1976a. A synopsis of the Costa Rican species of Burmeistera (Campanulaceae: Lobelioideae). Bulletin of the Torrey Botanical Club 102: 225-231

Wilbur, R.L. 1976b. Campanulaceae. In: R.E. Woodson Jr. \& R.W. Schery (eds.), Flora of Panama: part IX. Family 183. Annals of the Missouri Botanical Garden 63: 593-655.

Wilbur, R.L. 1981. Additional Panamanian species of Burmeistera (Campanulaceae: Lobelioideae). Annals of the Missouri Botanical Garden 68: $167-$ 171.

Wimmer, F.E. 1931. Lobelioideae aus dem Museum des königl. Botanischen Gartens zu Kew in England und einige aus anderen Sammlungen. Repertorium Specierum Novarum Regni Vegetabilis 29: 49-93, t. 115-118.

Wimmer, F.E. 1932. Burmeistera. Eine umstrittene Pflanzengattung und ihre Arten. Repertorium Specierum Novarum Regni Vegetabilis 30: 1-52, t. 123. 126.

Wimmer, F.E. 1943. Campanulaceae-Lobelioideae I. In: R. Mansfeld (ed.), Das Pflanzenreich IV (276b): i-viii, 1-260. W. Engelman, Berlin.

Wimmer, F.E. 1953. Campanulaceae-Lobelioideae II. In: R. Mansfeld (ed.), Das Pflanzenreich IV(276b): i-viii, 261-814. Akademie-Verlag, Berlin.

Wimmer, F.E. 1968. Campanulaceae-Lobelioideae Supplementum. In: H. Stubbe (ed.), Das Pflanzenreich IV(276c): i-x, 815-1024, Akademie-Verlag, Berlin.

Zahlbruckner, A. 1906. Campanulaceae andinae. Botanische Jabrbücher für Systematik, Pflanzengeschichte und Pflanzengeographie 37: 451-463.

Zahlbruckner, A. 1915. Neue Arten und Formen der Lobelioideen. I. Repertorium Specierum Novarum Regni Vegetabilis 13: 528-537.

Associate Editor: Javier Fuertes Received: 21-V-2012 Accepted: 8-X-2012 